Discussion Paper No. 01-48

Diffusion of Information Technology, Internet Use and the Demand for Heterogeneous Labor

Martin Falk

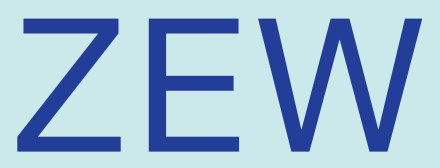

Zentrum für Europäische Wirtschaftsforschung GmbH

Centre for European Economic Research 

Discussion Paper No. 01-48

\title{
Diffusion of Information Technology, Internet Use and the Demand for Heterogeneous Labor
}

\author{
Martin Falk
}

Download this ZEW Discussion Papers from our ftp server:

ftp://ftp.zew.de/pub/zew-docs/dp/dp0148.pdf

Die Discussion Papers dienen einer möglichst schnellen Verbreitung von neueren Forschungsarbeiten des ZEW. Die Beiträge liegen in alleiniger Verantwortung der Autoren und stellen nicht notwendigerweise die Meinung des ZEW dar.

Discussion Papers are intended to make results of ZEW research promptly available to other economists in order to encourage discussion and suggestions for revisions. The authors are solely responsible for the contents which do not necessarily represent the opinion of the ZEW. 



\section{Non technical summary:}

This paper analyzes the link between the diffusion of information- and communication technology (ICT) and both the skill structure and employment expectations of the different skill categories at the firm level. We distinguish between six different worker categories: workers with a five- and four-year university degree, masters and technicians, workers with a certificate from the dual vocational system, unskilled workers as well as ICT workers.

The diffusion of ICT is emphasized as one of the most important factors explaining the shift in labor demand towards high-skilled or skilled workers and away from unskilled workers. Both ICT and the Internet have become an important presence in the workplace. According to a new comprehensive survey, almost one third of the employees in German firms now have Internet access. Furthermore, 43 percent of employees are using a computer on the job for at least half of their working time. The purpose for which computers are employed is also important. Approximately 62 percent of the German firms are users of enterprise resource planning (ERPs) software.

The main result is that firms with a greater penetration of ICT employ a larger fraction of workers with a university degree, in particular workers with a five-year degree. In contrast, a greater penetration of ICT tends to reduce the share of both medium-skilled and unskilled workers. Overall, the results are consistent with the technology-skill complimentarity hypothesis. The magnitude of the relationship between the penetration of ICT and the skill structure is relatively small for different educational qualifications and is somewhat higher for ICT workers. Most importantly, our findings indicate that the significantly positive relationship between ICT penetration and either high-skilled labor or ICT workers is considerably larger in the ICT sector than in the service or the manufacturing sector (excluding the ICT sector). Similarly, the significantly negative relationship between both unskilled or medium-skilled labor and the diffusion of ICT is more pronounced in the ICT sector and to a lesser extent in the service sector than in the manufacturing sector. Finally, the use of software applications such as ERP software, database management/datawarehouse software as well as $\mathrm{CAD} / \mathrm{CAE}$ is also a important determinant of the firms' skill structure. 


\title{
Diffusion of Information Technology, Internet
}

\section{Use and the Demand for Heterogeneous Labor}

\author{
Martin Falk*
}

\begin{abstract}
This paper analyzes the link between the diffusion of information- and communication technology (ICT) and both the skill structure and employment expectations of the different skill categories. The analysis is based on cross-sectional data for 4150 German firms conducted in mid-2000. The penetration of ICT is measured as the percentage of workers using a computer on the job for at least half of the working time, the number of computers per worker, percentage of workers with internet access, as well as the use of software applications such as ERP, CAD/CAE and database management systems. The empirical evidence indicates that firms with a higher diffusion of ICT employ a larger fraction of workers with a university degree as well as ICT specialists. Conversely, a greater ICT penetration is significantly negatively related to the share of both medium-skilled and unskilled workers. To account for censoring in the employment shares, the empirical analysis uses Powell's (1984) Censored Least Absolute Deviations estimator (CLAD). Furthermore, results of ordered probit models show that employment expectations for workers with a university degree are positively related to the degree of ICT penetration.
\end{abstract}

Keywords: diffusion of information technology, labor demand, skill structure, censored regression model JEL-Classification: C24, J23, O33, L80

\footnotetext{
* Center for European Economic Research, L7,1, D-68161 Mannheim; phone: (0621) 1235-153; fax: (0621) 1235-225; e-mail: falk@zew.de
} 


\section{Introduction}

The diffusion of ICT is emphasized as one of the most important factors explaining the shift in labor demand towards high-skilled or skilled workers and away from unskilled workers. Information and communication technologies as well as the Internet have become an important presence in the workplace. According to a comprehensive new survey, almost one third of the employees in German firms now have Internet access. ${ }^{1}$

The link between information and communication capital and the workforce's skill structure at the firm level has been empirically analyzed by a number of authors (for a survey of the literature see Chennells and Van Reenen, 1999). Using U.S. firm level panel data on 311 firms, Bresnahan, Brynjolfsson and Hitt (2000), found that ICT capital is positively correlated with investment in human capital and workforce skills. The authors conclude that skill-ICT complementarity is the dominant factor in explaining the demand for skilled labor. Doms, Dunne and Troske (1997) examine the effect of computer investment on the share of nonproduction workers using U.S. plant level data and found a significantly positive relationship. Similarly, Siegel (1998) uses plant level data to show that plants using more factory automation technologies employ more highly paid workers.

Bresnahan (1999) presents a theoretical firm-level based analysis of the impact of the expansion of ICT on the qualification structure of the workforce, dividing the role of ICT into two separate effects. On the one hand, the fall in demand for low- and medium-skilled labor results directly from the systematic substitution of computers for human decision-making. However, only a certain number of unskilled and medium-skilled tasks can be replicated by ICT, and thus only 'limited substitution' takes place. On the other hand, upon computerization of the production process, the demand for highly skilled workers who can efficiently use newly introduced ICT structures rises.

For Germany, Kaiser (2000) investigates the impact of information and com-

1 Following figures are based on the ZEW-infas IT survey 2000. All numbers are weighted using sample weights. They are constructed using information on the number of employment/firms in each cell as a share of total employment/firms based on the Employment Register of Social Security and the Microcensus. 
munication technologies on the demand for heterogeneous labor at the firm level. The data are used in this study are cross-sectional data on business related services taken from the Mannheim service innovation survey (MIP) 1997. The dependent variables are the firm's forecast of the change in net employment of three different skill groups over the next two years. Using a trivariate ordered probit model a positive impact of current ICT investment to total investment is detected for expected employment growth of university graduates and a significant negative impact revealed for the least skill groups.

Using a similar data set, Kukuk (2000) extends the previous analysis in the following ways. First, the author distinguishes between five educational qualification groups. Second, in order to account for the ordinal characteristics of the regressors an indirect estimation procedure is developed. Using a multivariate (seemingly unrelated) ordered probit model the author found that the ratio of ICT investment to total investment is positively related to the employment expectations of high-skilled labor and negatively related to unskilled labor.

Falk and Seim (2001a) analyze the link between educational qualification structure and the ICT investment output ratio. The analysis is based on 1996 crosssectional data (MIP 1997) for approximately 1,000 West German firms in service industries. Using both ML tobit and CLAD estimation techniques, the authors found that firms with a higher ICT investment output ratio employ a larger fraction of high-skilled workers at the expense of unskilled workers. To a lesser extent, the positive ICT effect carries through for workers with vocational degrees including masters and technicians. Furthermore, they found that firms' expectations of the future size of their high-skilled workforce are positively related to their initial ICT investment output ratio. Using panel data for about 900 West German firms over the period 1994-96, Falk and Seim (2001b) investigate the link between the high-skilled employment share and information technology (ICT) in the service sector. To account for the presence of zero observations in the high-skilled employment share, fixed and random effects tobit models are applied. Coefficients are allowed to vary across subsectors. The empirical evidence indicates that firms with a higher ICT investment output ratio employ a larger fraction of high-skilled workers. However, the size of the elasticity of the 
high skilled employment share with respect to the ICT-investment output ratio is rather small and is also sensitive to the estimation method that is employed. Elasticities based on the semi-parametric fixed effects tobit model are considerably lower than those estimated by the standard random effects ML tobit as well as pooled ML tobit model.

Using panel data for the period 1994 and 1996 (MIP 1995 and 1997), Jacobebbinghaus and Zwick (2001) found that innovation expenditures and investments in information and communication technologies lead to a lower employment share of workers with a certificate from the dual vocational system, whereas other investments lead to higher shares. In order to account for the censoring of the employment share the (CLAD) estimator and symmetrically censored least squares are employed. Firm-specific fixed or random effects, however, are not explicitly modelled.

This paper examines the relationship between the use and diffusion of information and communication technologies and the educational qualification structure. In particular, we distinguish between six separate skill categories, workers with a university degree (two types: four-year as well a five-year degrees), masters and technicians, workers with a certificate from the vocational school system, unskilled workers and ICT workers. Apprentices are excluded from the unskilled share. Our econometric work takes into account that a certain fraction of firms in the sample does not employ any workers of a given skill class. Apart from the standard ML Tobit, we employ Powell's (1984) censored least absolute deviations (CLAD) estimator which makes less restrictive assumptions about the functional form of the error term. This estimator is therefore preferable to the standard Tobit estimator in cases of heteroscedastic or non-normally distributed error terms. Furthermore, we also investigate the impact of ICT penetration on the employment expectations of different skill types.

We use a new data set that contains information on the diffusion and usage of ICT, the number of workers of different educational qualifications as well as the number of ICT workers. This survey contains both manufacturing and service firms. ICT diffusion is measured as percentage of workers using a computer on the job, the percentage of workers with internet access and the number of computers 
per worker. The data allows for a distinction between the use of various types of software applications, such as the use of ERP systems, database management systems and CAD/CAE tools (measured by a three point scale from "no use" to "heavy use"). Since networks link employees within the firm, the degree of connected computers may be a further determinant of both the skill intensity and the expected employment change.

This paper extends the previous literature in the following ways. First, the previous literature mainly focuses on the impact of information technology on different educational qualifications (see for example Autor, Katz and Krueger 1998). In this paper, we also analyze the relationship between ICT penetration and the employment share of ICT workers. Many types of information and communication technologies require ICT workers to install and maintain them. Therefore, we expect a significant larger effect of the usage of ICT on the share of ICT workers than on the share of high-skilled workers. Second, most previous studies using firm level data focus either on manufacturing or non-manufacturing firms. Kaiser (2000), Kukuk (2000) as well as Falk and Seim (2001a,b), for instance, only focus on the impact of ICT investment on three or five educational qualification groups in service firms. In this paper we distinguish between the manufacturing sector, the non-manufacturing sector, as well as the ICT sector. ${ }^{2}$ Furthermore, we also study the relationship of different types of ICT on the employment shares. Finally, most previous studies used the ICT capital stock or ICT investment as a share of total investment as a measure of ICT. However, it is well known that ICT investment is an imperfect measure of the adoption and diffusion of ICT because it does not take into account the effect of renting ICT equipment. In addition, firm level data on ICT investment are often measured with error or are missing.

The layout of the paper is as follows. Section 2 outlines the empirical model, while section 3 describes and summarizes the data. In section 4 , we present the results for the employment share equations as well as the determinants of employment expectations. Section 5 concludes.

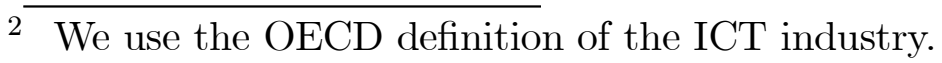




\section{Empirical Modelling}

\subsection{Employment share equations}

To examine the relationship between the usage of ICT and the educational qualification structure, employment shares of each skill class, $E_{i}^{k}$, are related to the different ICT penetration indicators, as well as a set of appropriate control variables ${ }^{3}$ :

$$
\begin{aligned}
E_{i}^{k}= & \alpha_{i k}+\beta_{1 j k} C O M P_{i} / E_{i}+\beta_{2 j k} E_{i}^{C O M P}+\beta_{3 j k} E_{i}^{W E B} \\
& +\beta_{4 j k} S W_{i}^{f}+\beta_{5 j k} C O M P_{i}^{n e t} / C O M P_{i}+\gamma_{j k} z_{i}+u_{i}
\end{aligned}
$$

where $k=H_{1}, H_{2}, M_{1}, M_{2}, U, I C T W ; i$ refers to the firm and $j$ to the industry. The variables are defined as: $E^{I C T W}$ $E^{H_{1}}$ $E^{H_{2}}$

The vector of control variables, $z$, contains sector, size and other control variables. The parameters $\beta_{1 j k}, \beta_{2 j k}, \beta_{3 j k}, \beta_{4 j k}$ and $\beta_{5 j k}$ measure the effects of ICT penetration on the skill structure of employment. A positive coefficient on $\beta_{3 j H_{1}}$

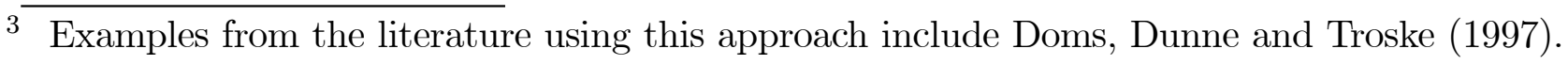


in the employment share equation for university graduates, for example, indicates that the percentage of workers with internet access, $E^{W E B} / E$, is a complement to workers with a university degree. In the empirical part of the paper, we calculate the elasticities of the employment shares with respect to the different ICT diffusion indicators:

$$
\begin{aligned}
\epsilon_{E^{k}, I C T^{l}} & =\frac{\partial E^{k}}{\partial I C T^{l}} \frac{I C T^{l}}{E^{k}}, \quad k=H_{1}, H_{2}, M_{1}, M_{2}, U, I C T W \\
l & =C O M P / E, E^{C O M P}, E^{W E B}
\end{aligned}
$$

ICT-skill complementarity is found if the elasticities increase with the skill level: $\left(\epsilon_{E^{H 1}, I C T^{l}}>\epsilon_{E^{H 2}, I C T^{l}}>\epsilon_{E^{M 1}, I C T^{l}}>\epsilon_{E^{M 2}, I C T^{l}}>\epsilon_{E^{U}, I C T^{l}}\right)$.

Before proceeding two caveats are in order. First, to carry out the empirical work relative wages have to be included into the employment share equations. Unfortunately, both the German Labor Force Survey as well as the employment register of social security statistics are limited in coverage to the period 1989-1997 and 1975-1995, respectively and thus do not overlap with our 2000 data. Given the limited availability of wage data at the industry level, we choose to capture the effects of relative wages by including sector dummies in the employment share equations. Industry dummies will pick up the effects of relative wage differences on labor demand if relative wages are constant within industries, but not across industries. Second, it would be preferable to include the stock of ICT capital in the employment share equations. However, longer time series on investment in ICT are not available. ICT expenditures or ICT investment as a share of total sales may be an alternative but the poor reliability and the large percentage of missing values prevented us from doing so. Therefore, we choose the percentage of workers using a computer on the job, the percentage of workers with internet access as well as the number of computers per worker as proxies of the diffusion of ICT. In addition, we also study the effects of the use of different software applications on the skill structure. 


\subsection{Estimation procedure}

\section{Censored regression model of the employment share equation}

The observed data on employment broken down into skill categories contains clusters of zero values leading to censored employment shares. Under censoring of the dependent variable, OLS estimates are inconsistent. A truncated regression model can be employed instead. In the basic censored regression model with left censoring, the true underlying dependent variable, $y^{*}$, is a function of a set of independent variables, $x$ :

$$
y^{*}=x \beta+\varepsilon \quad \varepsilon \sim N\left(0, \sigma^{2}\right)
$$

where $\varepsilon$ denotes the error term and $\beta$ the vector of coefficients. The observed value of the dependent variable, $y$, is given by:

$$
y= \begin{cases}L & y^{*} \leq L \\ y^{*}=x \beta+\varepsilon & y^{*}>L\end{cases}
$$

with $L$ being the lower censoring bound. ${ }^{4}$

An alternative estimation procedure for the employment share equations follows Powell's (1984, 1986) semi-parametric estimators for censored regression models, the Censored Least Absolute Deviations (CLAD) or Symmetrically Censored Least Squares (SCLS) estimators. Both estimators perform, under certain circumstances, better than the standard ML-Tobit model due to robustness to heteroscedasticity or other forms of distributional misspecification. While the SCLS estimator is more efficient than the CLAD estimator, the CLAD estimator is more robust to outliers, which arise very frequently in the case of survey data due to erroneous responses. The CLAD estimator can be motivated starting from the basic Tobit model by rewriting equations 2.2 and 2.3 as:

$$
y=\max (x \beta+\varepsilon, L)
$$

\footnotetext{
4 We do not consider censoring in the upper tail of the distribution for each of the employment shares since the percentage of right-censored observations is negligible (approximately less than 1 percent of all observations, see Table 4).
} 
The CLAD estimator of $\beta$ minimizes the sum of absolute deviations, $|\varepsilon|$, assuming a conditional median restriction on the error term. The objective function can thus be specified as:

$$
S_{n}(\beta)=\min \beta\left\{\frac{1}{n} \sum_{i=1}^{n}\left|y_{i}-\max \left\{L, \beta^{\prime} x_{i}^{\prime}\right\}\right|\right\}
$$

The CLAD estimator uses the observation so that the median is preserved by monotone functions. Hence, at the presence of censored data, the median of the observations is identical before and after censoring. The CLAD estimator's performance has been shown to be sensitive to the degree of censoring. In our sample, however, censoring at the lower bound, zero, ranges only from 7 percent for workers with a certificate from the dual vocational system to 34 percent for unskilled workers (see Table 4). Approximately, 31 percent of the firm do not employ ICT workers. The sample's degree of censoring falls, therefore, well within the limits specified by McDonald and Xu (1996) validating the use of CLAD procedures. Paarsch (1984) points to a further weakness of the CLAD estimator, namely its finite sample bias resulting in mean-biased results for small samples $(n<100)$. In such cases, the standard Tobit MLE produces superior results with smaller standard errors than Powell's CLAD. Therefore, we base a comparison of Tobit MLE and CLAD only on large subsample sizes with at least 500 observations instead of the smaller industry-level subsamples. A final difficulty arising in the application of the CLAD estimator is computational rather than conceptional. The CLAD estimator involves the minimization of an objective function that is not necessarily convex in $\beta$. Thus, obtaining a global minimum of the objective function using numerical minimization algorithms based on approximations of the first derivative can be difficult, and convergence to a global minimum cannot necessarily be guaranteed. We use ML Tobit as well as least absolute deviations (LAD) estimates as starting values and also experiment with different starting conditions to check for the presence of other minima. Following Melenberg and Van Soest (1996) we employ the Simplex Nelder-Mead algorithm to minimize the objective function. ${ }^{5}$ A different estimation technique

\footnotetext{
5 We apply the Nelder-Mead simplex algorithm included in the GMAXIM Gauss package.
} 
of the CLAD estimator is the iterative linear programming algorithm (ILPA) suggested by Buchinsky (1991) and implemented in STATA 7 as ado file (see Jolliffe et al. 2000). ${ }^{6}$ My experience has been that this estimator fails to converge several times. The difference in the estimates between both algorithms used for the CLAD estimator, however, is very small. Furthermore, since the estimator's asymptotic variance-covariance matrix (as specified by Powell, 1984) involves the estimation of the density function of the error term, we use bootstrap estimates of the standard errors with about 500 draws. Here, the standard errors are obtained by a simple random draw. ${ }^{7}$ The underlying assumption is that the data are a random sample from the total population. Finally, each employment share equation can be estimated efficiently using single equation censored regression model. This can be justified by the fact the right hand variables are similar across the equations. In addition, in the absence of factor prices is not necessary to impose the conditions of symmetry and linear homogeneity in factor prices.

\section{Ordered Probit equations explaining the expected change in the employment of the five skill types}

The previous specification of the employment share equations analyzes the relationship between ICT diffusion indicators and the skill intensity of the firm. To estimate the influence of ICT on the expected change in employment we choose to use ordered probit models. Let $\widetilde{Y}_{i l}^{*}$ denote the unobserved desired employment change for firm $\mathrm{i}$ and let $x_{1 i}, x_{2 i}, \ldots x_{m i}$, be a vector of explanatory variables for firm i. Define

$$
\tilde{Y}_{i l}^{*}=b_{1} x_{1 i}+b_{2} x_{2 i}+. .+b_{m} x_{m i}+u_{i}
$$

\footnotetext{
For a critique of the ILPA techniques see Fitzenberger 1997 (cited in Jolliflle et. al. 2000).

7 Note that the sample is stratified on industry affiliation, firm size and region. Since the sample is not a pure random sample the standard bootstrap procedure will not accurately reflect the characteristics of the data. In order to account for the stratification the bootstrap procedure can be adjusted using sample weights. These weights are constructed using information on the proportion of firms in each cell to total propulation so that between the cells/clusters each firm has unequal probability of being chosen. Preliminary estimates suggest that standard errors based on a two-stage procedure are very close to those using a simple random draw, in particular for the subsamples. Since the two-stage bootstrap procedure is very time-consuming, we focus on the standard bootstrap procedure.
} 
where the underlying dependent variable $\widetilde{Y}_{i l}$ indicates three different categories of expected employment change for the five different types of labor $l=U, M_{1}, M_{2}$, $H_{1}, H_{2}$ from period $t$ to period $t+1$. The observed categories are defined as follows:

$$
\begin{array}{rll}
\text { firm i reports down }: & \tilde{Y}_{i l}=0 \text { if } \widetilde{Y}_{i l}^{*} \leq k_{l 0} \\
\text { firm i reports the same }: & \widetilde{Y}_{i l}=1 \text { if } k_{l 0}<\widetilde{Y}_{i l}^{*} \leq k_{l 1} \\
\text { firm i reports up }: & \widetilde{Y}_{i l}=2 \text { if } \widetilde{Y}_{i l}^{*}>k_{l 2} .
\end{array}
$$

The parameters chosen will maximize the likelihood of the observed sample over $\mathrm{i}=1,2, . ., \mathrm{n}$ firms. The $x / s$ denote the ICT diffusion indicators such as the percentage of workers with internet access, percentage of workers using a computer on the job, the number of computers per worker, the use of different software applications as well as control variables (expected demand change, size, sector dummies). The expected sign for the ICT coefficients of the employment equation are positive in the case of high-skilled workers and negative for unskilled workers. Single equation ordered probit models provide consistent estimates of the parameters. A multivariate ordered probit model, i.e SUR ordered probit model, may be more efficient depending on the correlation of the error terms. In practice, however, the efficiency gains are very small. Breslaw and McIntosh (1998) pointed out that with 5000 observations single equation ordered probit estimates were almost identical to estimates from a multivariate ordered probit model.

Marginal effects are calculated as follows:

$$
\frac{\partial \operatorname{Prob}[y=0]}{\partial x}=-\phi\left(\gamma_{1}-\beta^{\prime} x\right) \beta
$$

and

$$
\frac{\partial \operatorname{Prob}[y=2]}{\partial x}=-\phi\left(\gamma_{2}-\beta^{\prime} x\right) \beta
$$

where $\phi(\cdot)$ denotes the density function of the normal distribution. 


\subsection{Hypotheses}

Bresnahan (1999) presents a theoretical analysis of the impact of the expansion of ICT on the qualification structure of the workforce, dividing the role of ICT into two separate effects. On the one hand, the fall in demand for low- and medium-skilled labor results directly from the systematic substitution of computers for human decision-making. However, only a certain number of unskilled and medium-skilled tasks can be replicated by ICT, and thus only 'limited substitution' takes place. An example of a task that cannot be covered by ICT includes front office staff. On the other hand, upon computerization of the production process, the demand for highly skilled workers who can efficiently use newly introduced ICT structures rises. The magnitude of restructuring due to computerization may vary by the type of organization. Bresnahan argues that the impact of new ICT innovations may be limited in 'people-based' organizations, which rely strongly upon personal communication. Conversely, in software-based production, the same innovation can be easily supplied to all customers and suppliers, leading to an increased marginal product of the creators of new ideas. This process of 'organizational complementarity' is likely to be more pronounced at the firm level than at the employee level. A number of implications for empirical investigations of the role of ICT in today's workforce arise. First, the effect of ICT should be examined at the firm level since we expect benefits for both the organization and the individual employee. Second, the usage of ICT may have a negative impact on both the demand for medium- and unskilled workers. These effects, however, should be relatively small. Finally, only the highest skill group, in particular professionals and managers, can be expected to benefit from computerization. Similarly, Bartel and Lichtenberg (1987) argue that firms will hire more highly skilled labor in the aftermath of technological changes. This can be justified by the fact that they have a comparative advantage in implementing new technologies due to their ability of solving problems and adapting to changes in the work environment.

In the following, we advance five hypotheses concerning the relationship between the skill structure of workers and the usage of information technology, 
which we proceed to evaluate in the following empirical work:

Hypothesis 1. ICT-skill complementarity: Highly educated labor is complementary rather than a substitute for ICT. Conversely, ICT is a substitute for both unskilled and medium-skilled labor. Furthermore, we also expect that different types of ICT are positively related to the employment expectations of highly skilled labor.

Hypothesis 2. The hypothesis of 'limited substitution' predicts that the magnitude of effects of ICT on both medium-skilled and unskilled labor should be relatively small.

Hypothesis 3 . The share of ICT workers should be strongly positive related to the diffusion of ICT. This can be explained by the fact that these occupations are directly related to the use of information and communication technologies. For instance, many information and communication technologies such as ERP software or data management software/systems require skilled ICT workers or high skilled workers to install and maintain them.

Hypothesis 4. The ranking of the ICT employment share elasticities holds most strongly in sectors which rely heavily on information technology such as the service sector as well as the ICT sector. The negative effect of ICT on medium-skilled as well as on unskilled labor should be larger in services than in manufacturing. This can be justified by the fact that computer technology is often associated with routinization of many simple and repetitive white collar tasks, such as clerical tasks (see Autor et al. 1998, Bresnahan 1999).

Hypothesis 5. The effects of information and communication technologies on the skill structure also depend on the type of ICT. Doms et al. (1997), for instance, found that the effects of information and communication technologies on the skill structure depend on the types of technology being adopted. Internet penetration as well as the percentage of workers using a computer on the job may have different effects on the skill structure. Furthermore, the use of complex software applications (such as ERP or database management software) should also require a higher share of highly skilled workers as well as ICT workers. 


\section{Data description}

Our empirical analysis is based on a new data set that contains information of the diffusion and usage of ICT, shortages of ICT workers, skill needs and the general educational qualification structure. The survey is nationally representative and stratified by sector, size and region. Firms belonging to the ICT sector, for instance, are overrepresented. The survey was collected between August and October 2000 and contains information for 1999 and 2000.

The survey covers manufacturing, retail and wholesale trade, transport, banking and insurance, business services and the ICT sector representing a population of about 15 million workers. The definition of ICT-sector follows the OECD definition and includes: office machinery and computers (300), wire and cables (313), radio, television and communication equipment (321-323), instruments and appliances (332), industrial process control equipment (333). wholesale of office machinery (51641), retail sales of optical and photographic goods, computers and software (52484), telecommunications (642), renting of office machinery and computers (7133) and software and data processing (72).

Approximately 4400 firms participated in the first wave. The key variables in this study include three different information technology indicators (computers per worker, percentage of workers using a computer on the job and percentage of workers with internet access) as well as penetration indicators of software applications (use of data management systems, ERP software, CAD, use of email and electronic data exchange).

Following questions were asked (all data refer to mid 2000 except where otherwise indicated):

- What proportion of employees in your firm uses PCs, workstations or terminals for half or more of the working time?

- Approximately what percentage of the PCs, workstations or terminals are networked or interconnected?

- Number of PCs, workstations or terminals?

- Which of the following software applications are used by employees in your firms? (Three categories: widespread use, occasional use, no use): (i) Of- 
fice software packages such as word processing and spreadsheet programs, (ii) archives and database management system, (iii) Software for planning, operations management, and controlling (for instance enterprise resource planning systems), (iv) CAD (computer aided design) and CAM (computer aided manufacture) or CAE (computer aided engineering), (v) electronic data exchange and (vi) exchange of e-mail.

- Can your employees access Internet? (yes/no) and if so, approximately what proportion of employees in your firm has internet access?

- What is the number of skilled ICT workers in 1999 and 2000? (excluding ICT apprentices).

- What is the proportion or the total number of employees of five different educational qualification categories in 1999 (workers with a five-year university degree, workers with a four-year university degree, masters and technicians, workers with a certificate from the dual vocational system, workers with no formal qualification as well as apprentices).

- Employment expectations for five skill categories as well as ICT workers between 2000 and 2002 (0 for decrease, 1 for unchanged employment and 2 for increase).

The definition of ICT workers is rather broad covering computer occupations such as computer programmers, system analysts and computer engineers/scientists as well as persons engaged primarily in the conception, design, training, support of information technology systems, components or applications. ICT workers, for instance, include: computer programmers, computer software engineers, system analysts, network administrators, computer support specialists, telecommunication engineers, telecommunication technicians, hardware engineers, computer science teachers and training specialists, database administrators and managers. For ICT workers item non-response is very low. Approximately 1 percent of firms did not report their number of ICT workers.

Skill structure is measured by the employee's level of educational qualification. Two types of high-skilled workers are available. The first group denotes employees with a five-year university degree and the second group with a four-year 
university degree from a technical college ('University of Applied Sciences').

Excluding firms with less than 5 employees led to a reduction of the sample to 4149 firms. Incomplete information on the ICT variables as well as the expected employment change variables further reduced the sample by 565 firms. Furthermore, a large number of firms refused the answer on the educational qualification structure (702 firms). Therefore, we work with two sample sizes depending on the set of dependent variables.

Table 1: Summary statistics, ICT indicators

\begin{tabular}{|c|c|c|c|c|c|c|c|}
\hline & Mean $\dagger$ & $\begin{array}{l}\text { Me- } \\
\text { dian }\end{array}$ & $\begin{array}{l}\text { Std. } \\
\text { dev }\end{array}$ & Min. & Max. & $\begin{array}{r}\mathrm{x}=0^{b} \\
\text { per }\end{array}$ & $\begin{array}{l}x=1^{b} \\
\text { ent }\end{array}$ \\
\hline & \multicolumn{7}{|c|}{ total sample (weighted $)^{a}($ obs $=4149)$} \\
\hline computers per worker, $\%$ & 51.3 & - & 61.4 & 0 & 800 & 0.7 & 5.8 \\
\hline$\%$ of workers using computers & 43.2 & - & 34.6 & 0 & 100 & 1.8 & 13.1 \\
\hline$\%$ of workers with internet access & 27.8 & - & 31.4 & 0 & 100 & 6.1 & 15.6 \\
\hline \multirow[t]{2}{*}{$\%$ of ICT workers } & 4.7 & - & 15.2 & 0 & 100 & 34.5 & 1.3 \\
\hline & \multicolumn{7}{|c|}{ estimation sample 1 (unweighted) (obs=3756) } \\
\hline computers per worker, $\%$ & 60.0 & 44.1 & 55.7 & 0 & 800 & 0.6 & 5.6 \\
\hline$\%$ of workers using computers & 46.7 & 40.0 & 32.4 & 0 & 100 & 1.5 & 12.7 \\
\hline$\%$ of workers with internet access & 33.4 & 20.0 & 35.4 & 0 & 100 & 5.8 & 15.6 \\
\hline \multirow[t]{2}{*}{$\%$ of ICT workers } & 8.8 & 1.2 & 20.6 & 0 & 100 & 33.5 & 1.1 \\
\hline & \multicolumn{7}{|c|}{ estimation sample 2 (unweighted) (obs=2947) } \\
\hline computers per worker, $\%$ & 60.0 & 44.1 & 53.4 & 0 & 800 & 0.8 & 5.4 \\
\hline$\%$ of workers using computers & 46.9 & 40.0 & 32.2 & 0 & 100 & 0.9 & 12.4 \\
\hline$\%$ of workers with internet access & 33.6 & 20.0 & 35.1 & 0 & 100 & 4.8 & 15.2 \\
\hline$\%$ of ICT workers & 8.8 & 1.3 & 20.2 & 0 & 100 & 31.2 & 1.0 \\
\hline
\end{tabular}

Source: ZEW-infas IT survey 2000.

Tables 1-3 provide some insights into the sample data. Table 1 contains information on the three main information technology indicators. The number of computers (PCs, mainframes as well as terminals) per total workers amounts to 51 percent in 2000 (weighted by sample weights). Approximately 43 percent of the employees are using a computer on the job for at least half of their working time in 2000. The relatively high share of workers using a computer on the job highlights the significant role that ICT takes in the production process. Based 
on the German Micro Census 2000, a survey at the individual level, 54 percent are working with a computer on the job (see Statistics Germany 2001). The difference between the two data sources may be related to the limited coverage of our survey. Government, non-profit institutions, health sector as well as construction are not included in our survey. Furthermore, unreported descriptive statistics show that the use of computers on the job is more common in the ICT sector as well as in skill-intensive services than in manufacturing. The mean percentage of employees working with a computer in services (excluding ICT services) is 45 percent and therefore considerably higher than in manufacturing (excluding ICT sector) with 34 percent. $^{8}$ Within the service sector, the use of a computer is most common in banking and insurance with a mean percentage of 75 percent. In the ICT sector the corresponding share is 68 percent. The internet has also become increasingly important in the workplace. Almost one third of the employees in the sample now has Internet access (weighted by sample weights). The mean percentage of workers with internet access ranges between 21 percent in manufacturing (excluding ICT sector), 35 percent in non-manufacturing and 69 percent in the ICT sector. Table 1 also contains the share of ICT workers. The mean percentage of total employment in these occupational groups is about 4.7 percent (weighted by sample weights) (see Table 1). Unreported results show that the share of ICT workers range between 2.3 percent in manufacturing and 36 percent in the ICT sector. The survey also contains information on the share of connected PCs, mainframes and terminals. This variable is regrouped into four categories, ranging from no use to 49 percent, between 50 and 74 percent, 75 to 99 percent and 100 percent. As many as 50 percent of the firms report that computers are completely connected and a further 13 percent of the firms report that the share of connected computers ranges between 75 and 99 percent (see Table 2).

Our survey also requested information on whether computers are used for each of six purposes, and if so, the level of use on a 2 point scale from small use to heavy use (see Table 2). In 2000, 62 percent of German firms report a use of ERP software (among them 25 percent of the firms are heavy users and 36

\footnotetext{
8 All figures are weighted by sample weights.
} 
Table 2: Summary statistics, use of software applications

\begin{tabular}{lrr}
\hline \hline & $\begin{array}{c}\text { Total sample } \\
\text { weighted } \\
\text { use of software applications: }\end{array}$ & $\begin{array}{c}\text { Estimation sample } \\
\text { unweighted } \\
\text { (obs=3756) }\end{array}$ \\
\hline database management, widespread & 31.6 & 42.8 \\
database management, occasional & 39.5 & 42.2 \\
ERP systems, widespread & 25.4 & 36.5 \\
ERP systems, occasional & 36.3 & 46.1 \\
CAD/CAE, widespread & 12.6 & 18.0 \\
CAD/CAE, occasional & 19.7 & 38.0 \\
E-mail use, widespread & 38.5 & 67.3 \\
E-mail use, occasional & 40.0 & 25.5 \\
share of connected computers, 50-74\% & 8.7 & 7.3 \\
share of connected computers, 75-99\% & 13.2 & 19.8 \\
share of connected computers, 100\% & 51.1 & 61.7 \\
\hline \hline
\end{tabular}

Source: ZEW-infas IT survey 2000.

percent occasional users). The number of firms using e-mail systems amounts to 79 percent (among them 39 percent of the firms are heavy users and 40 percent are small users). The number of firms using data management/datawarehouse software applications is 72 percent (among them 32 percent are heavy users and 40 percent are small users).

Table 3 contains information on the employment expectations between 2000 and 2002. The responses are coded as 0 for decrease, 1 for unchanged employment and 2 for increase. In general, employment expectations increase with the skill level. Table 4 contains summary statistics on the educational qualification structure. The proportion of university graduates is 12 percent, 11 percent of the workers have a technical university degree, and 11 percent of the workers masters and technicians. Approximately 44 percent of the workers have a certificate from the dual vocational system, while workers without any advanced degree account for approximately 17 percent of the sample. Apprentices are separated and account for 5 percent of the employees. The skill structure varies considerably across service industries. Among computer and software firms, 50 percent of employees have an university or technical university degree, while only 
Table 3: Employment expectations (percentage share of total), unweighted

\begin{tabular}{lccr}
\hline \hline Employment shares: & $\begin{array}{c}\text { increase } \\
\text { estimation }\end{array}$ & $\begin{array}{c}\text { unchanged } \\
\text { sample }\end{array}$ & \multicolumn{1}{c}{$\begin{array}{c}\text { decrease } \\
\text { (obs=3756) }\end{array}$} \\
\hline Five-year university degree & 35.5 & 61.3 & 3.2 \\
Four-year university degree & 41.8 & 54.9 & 3.3 \\
Masters and technicians, & 32.6 & 61.3 & 6.1 \\
Vocational degree, & 44.8 & 44.6 & 10.7 \\
Without any formal qualification & 12.2 & 62.0 & 25.9 \\
& total sample (obs=3995) \\
Five-year university degree & 35.8 & 61.1 & 3.1 \\
Four-year university degree & 42.0 & 54.8 & 3.2 \\
Masters and technicians & 32.2 & 61.6 & 6.2 \\
Vocational degree & 44.3 & 44.9 & 10.9 \\
Without any formal qualification & 12.0 & 61.8 & 26.2 \\
\hline \hline
\end{tabular}

Source: ZEW-infas IT survey 2000.

Table 4: Summary statistics, educational qualification structure in 1999, unweighted

\begin{tabular}{lrrrrrrr}
\hline \hline $\begin{array}{l}\text { Employment shares } \\
\text { (percentages): }\end{array}$ & $\begin{array}{r}\text { Mean } \dagger \\
\text { Five-year university degree }\end{array}$ & $\begin{array}{r}\text { Me- } \\
\text { dian }\end{array}$ & $\begin{array}{r}\text { Std. } \\
\text { dev }\end{array}$ & Min. & Max. & $\begin{array}{r}\mathrm{x}=0^{b} \\
(\%)\end{array}$ & $\begin{array}{r}\mathrm{x}=1^{b} \\
(\%)\end{array}$ \\
\hline Four-year university degree & 12.4 & 5.0 & 17.7 & 0 & 100 & 21.4 & 0.1 \\
Masters and technicians & 11.2 & 5.8 & 12.9 & 0 & 100 & 18.9 & 0.0 \\
Vocational degree & 44.2 & 46.0 & 26.5 & 0 & 100 & 6.8 & 0.6 \\
Unskilled labor & 16.9 & 7.0 & 22.4 & 0 & 100 & 34.2 & 0.1 \\
Apprentices & 4.5 & 3.0 & 6.4 & 0 & 81.7 & 32.0 & 1.0 \\
\hline \hline
\end{tabular}

Notes: †Arithmetic means, estimation sample $2(\mathrm{obs}=2947)$.

Source: ZEW-infas IT survey 2000. 
5 percent of retail trade employees are university-educated.

\section{Empirical Results}

\subsection{CLAD estimates for the employment share equations}

In order to quantify the main factors behind the skill structure, the employment shares are regressed against the potential determinants discussed above. As noted earlier, the percentage share of zero values ranges between 7 percent for the employment share of workers with a certificate from the dual vocational system and 34 percent for the unskilled employment share. For ICT worker share the percentage of zero values is 31 percent. Table 5 reports the CLAD estimation results for the five skill classes as well as for the share of ICT workers. ${ }^{9}$ Estimation results of ML Tobit model are reported in Table 6. Since estimates using sample weights, which correct for the stratification plan, are very close to those reported here, I do not correct for the stratification plan. Likelihood ratio test, which tests the assumption of multiplicative heteroscedastic errors versus the homoscedastic base model, can not be rejected at the 5 percent level. The CLAD and Tobit estimates, however, are qualitatively quite similar but quantitatively different in most of the cases. The difference in the coefficients is relatively moderate. For the employment share of different educational qualifications, standard ML Tobit tends to overestimate the coefficients on both the percentage of workers using a computer on the job and the percentage of workers with internet access between 15 and 30 percent in absolute terms depending on the different employment shares. In contrast, standard ML Tobit tends to underestimate the coefficient on the ratio of computers per worker.

\footnotetext{
9 CLAD estimates of the parameters were computed using both GAUSS and MATLAB programs. I thank Johannes Ludsteck for the MATLAB program.
} 
Table 5: Determinants of the skill structure (CLAD estimates)

\begin{tabular}{|c|c|c|c|c|c|c|}
\hline & $\begin{array}{c}\text { ICT } \\
\text { workers }\end{array}$ & $\begin{array}{l}\text { ependent } \\
\text { university } \\
\text { five- }\end{array}$ & $\begin{array}{l}\text { variables } \\
\text { degree } \\
\text { four- }\end{array}$ & $\begin{array}{c}\text { : employr } \\
\text { masters, } \\
\text { tech- }\end{array}$ & $\begin{array}{l}\text { ent share } \\
\text { vocat- } \\
\text { ional }\end{array}$ & $\begin{array}{c}\text { un- } \\
\text { skilled }\end{array}$ \\
\hline & & year & year & nicians & school & \\
\hline computers p. worker & $\begin{array}{l}0.079 \\
(2.15)\end{array}$ & $\begin{array}{c}0.109 \\
(8.01)\end{array}$ & $\begin{array}{c}0.046 \\
(4.69)\end{array}$ & $\begin{array}{c}0.001 \\
(0.76)\end{array}$ & $\begin{array}{c}-0.077 \\
(-3.74)\end{array}$ & $\begin{array}{c}-0.221 \\
(-5.41)\end{array}$ \\
\hline$\%$ using a computer & $\begin{array}{l}0.219 \\
(6.65)\end{array}$ & $\begin{array}{c}0.016 \\
(1.03)\end{array}$ & $\begin{array}{c}0.036 \\
(3.39)\end{array}$ & $\begin{array}{c}0.010 \\
(1.30)\end{array}$ & $\begin{array}{c}-0.071 \\
(-2.44)\end{array}$ & $\begin{array}{c}-0.096 \\
(-2.54)\end{array}$ \\
\hline$\%$ with internet access & $\begin{array}{c}0.105 \\
(5.18)\end{array}$ & $\begin{array}{c}0.099 \\
(6.18)\end{array}$ & $\begin{array}{c}0.032 \\
(3.30)\end{array}$ & $\begin{array}{c}0.007 \\
(0.92)\end{array}$ & $\begin{array}{c}-0.116 \\
(-4.25)\end{array}$ & $\begin{array}{c}-0.077 \\
(-2.62)\end{array}$ \\
\hline databases, widespread & $\begin{array}{c}0.208 \\
(2.69)\end{array}$ & $\begin{array}{c}0.014 \\
(3.61)\end{array}$ & $\begin{array}{c}0.010 \\
(1.42)\end{array}$ & $\begin{array}{c}-0.014 \\
(-1.73)\end{array}$ & $\begin{array}{c}0.031 \\
(1.61)\end{array}$ & $\begin{array}{c}-0.007 \\
(-0.70)\end{array}$ \\
\hline database, occasional & $\begin{array}{c}0.136 \\
(1.73)\end{array}$ & $\begin{array}{c}0.013 \\
(1.91)\end{array}$ & $\begin{array}{c}0.007 \\
(1.01)\end{array}$ & $\begin{array}{c}-0.016 \\
(-2.04)\end{array}$ & $\begin{array}{c}0.028 \\
(1.49)\end{array}$ & $\begin{array}{c}-0.005 \\
(-1.92)\end{array}$ \\
\hline ERP, widespread & $\begin{array}{c}-0.004 \\
(-0.54)\end{array}$ & $\begin{array}{c}0.018 \\
(1.31)\end{array}$ & $\begin{array}{c}0.013 \\
(1.61)\end{array}$ & $\begin{array}{c}0.025 \\
(3.28)\end{array}$ & $\begin{array}{c}-0.024 \\
(-1.54)\end{array}$ & $\begin{array}{r}0.007 \\
(1.12)\end{array}$ \\
\hline ERP, occasional & $\begin{array}{c}-0.034 \\
(-1.19)\end{array}$ & $\begin{array}{c}0.020 \\
(1.48)\end{array}$ & $\begin{array}{c}0.011 \\
(1.35)\end{array}$ & $\begin{array}{c}0.019 \\
(2.41)\end{array}$ & $\begin{array}{c}-0.005 \\
(-0.37)\end{array}$ & $\begin{array}{c}-0.003 \\
(-0.22)\end{array}$ \\
\hline CAD, widespread & $\begin{array}{c}-0.026 \\
(-0.92)\end{array}$ & $\begin{array}{c}-0.002 \\
(-0.29)\end{array}$ & $\begin{array}{l}0.024 \\
(4.17)\end{array}$ & $\begin{array}{c}0.016 \\
(2.45)\end{array}$ & $\begin{array}{c}0.011 \\
(1.11)\end{array}$ & $\begin{array}{c}-0.092 \\
(-4.53)\end{array}$ \\
\hline CAD, occasional & $\begin{array}{c}-0.093 \\
(-2.44)\end{array}$ & $\begin{array}{c}0.010 \\
(1.42)\end{array}$ & $\begin{array}{c}0.002 \\
(0.52)\end{array}$ & $\begin{array}{c}0.013 \\
(2.67)\end{array}$ & $\begin{array}{c}-0.003 \\
(-0.80)\end{array}$ & $\begin{array}{c}-0.017 \\
(-1.25)\end{array}$ \\
\hline Email, widespread & $\begin{array}{c}-0.023 \\
(-0.44)\end{array}$ & $\begin{array}{c}0.018 \\
(1.27)\end{array}$ & $\begin{array}{c}0.015 \\
(1.94)\end{array}$ & $\begin{array}{c}0.004 \\
(1.06)\end{array}$ & $\begin{array}{l}0.001 \\
(-0.58)\end{array}$ & $\begin{array}{c}0.001 \\
(0.89)\end{array}$ \\
\hline Email, occasional & $\begin{array}{c}0.001 \\
(0.78)\end{array}$ & $\begin{array}{c}0.016 \\
(1.31)\end{array}$ & $\begin{array}{c}0.011 \\
(1.49)\end{array}$ & $\begin{array}{c}0.009 \\
(1.80)\end{array}$ & $\begin{array}{c}-0.001 \\
(-0.45)\end{array}$ & $\begin{array}{c}0.001 \\
(0.03)\end{array}$ \\
\hline East Germany & $\begin{array}{c}0.015 \\
(0.44)\end{array}$ & $\begin{array}{c}0.048 \\
(4.50)\end{array}$ & $\begin{array}{c}0.023 \\
(4.26)\end{array}$ & $\begin{array}{c}-0.011 \\
(-2.60)\end{array}$ & $\begin{array}{c}0.072 \\
(4.66)\end{array}$ & $\begin{array}{c}-0.222 \\
(-8.38)\end{array}$ \\
\hline part of a group & $\begin{array}{c}0.007 \\
(0.47)\end{array}$ & $\begin{array}{c}0.012 \\
(1.76)\end{array}$ & $\begin{array}{c}0.000 \\
(0.08)\end{array}$ & $\begin{array}{c}0.003 \\
(0.80)\end{array}$ & $\begin{array}{c}0.004 \\
(0.88)\end{array}$ & $\begin{array}{c}-0.016 \\
(-1.34)\end{array}$ \\
\hline foreign subsidiary & $\begin{array}{c}-0.053 \\
(-1.20)\end{array}$ & $\begin{array}{c}0.012 \\
(1.89)\end{array}$ & $\begin{array}{c}0.008 \\
(1.87)\end{array}$ & $\begin{array}{c}0.006 \\
(2.81)\end{array}$ & $\begin{array}{c}-0.021 \\
(-1.58)\end{array}$ & $\begin{array}{c}-0.001 \\
(-0.13)\end{array}$ \\
\hline size, sector dummies & yes & yes & yes & yes & yes & yes \\
\hline constant & $\begin{array}{c}0.014 \\
(3.61)\end{array}$ & $\begin{array}{c}-0.198 \\
(-9.07)\end{array}$ & $\begin{array}{c}-0.075 \\
(-4.22)\end{array}$ & $\begin{array}{c}0.083 \\
(3.95)\end{array}$ & $\begin{array}{l}0.518 \\
(16.58)\end{array}$ & $\begin{array}{c}0.261 \\
(6.72)\end{array}$ \\
\hline scale factor & .572 & .723 & .745 & .713 & .957 & .630 \\
\hline$\epsilon:$ comp. per worker ${ }^{a}$ & $0.31^{* *}$ & $0.38^{* *}$ & $0.20^{* *}$ & 0.00 & $-0.10^{* *}$ & $-0.50^{* *}$ \\
\hline$\epsilon: \%$ using computers ${ }^{a}$ & $0.67^{* *}$ & 0.04 & $0.12^{* *}$ & 0.03 & $-0.07^{* *}$ & $-0.17^{* *}$ \\
\hline$\epsilon: \%$ internet $^{\text {access }^{a}}$ & $0.23^{* *}$ & $0.19^{* *}$ & $0.08^{* *}$ & 0.01 & $-0.08^{* *}$ & $-0.10^{* *}$ \\
\hline
\end{tabular}

Notes: Elasticities of the employment share with respect to ICT (converted into marginal effects). t-values are based on bootstrap standard errors with 500 draws. ${ }^{* *}(*)$ denote significant at the 5 (10) percent level. Obs.: 2947. 
The central result to be drawn from the CLAD estimates is the significant relationship between firms' skill structure and the penetration of information and communication technology (see Table 5). Each of the three primary indicators (computers per worker, percentage of workers using a computer on the job as well as the percentage of workers with internet access) are significant at the one percent level in most of the cases. Notable exceptions are the impact of ICT on masters and technicians as well as the coefficient on the percentage of workers using a computer on the job in the employment share equation of workers with a five-year university degree. As expected, the relationship between ICT penetration is significantly positive for both high-skilled labor shares and significantly negative for workers with a certificate from the dual vocational system as well as for unskilled labor. This indicates that high-skilled labor serves as a complement to ICT confirming our first hypothesis. Conversely, both medium- and unskilled labor are substitutable to ICT. In addition, we find that firms with a greater ICT penetration employ a larger fraction of ICT workers.

To shed light on the magnitude of the relationship between the usage of ICT and the employment share we convert coefficients into elasticities. These elasticities measure the percentage change of the different employment shares with respect to a 1-percent increase in one of the three ICT penetration indicators (see Table 5 shown at the bottom). In general, the magnitude of these elasticities is rather small with higher elasticities for ICT workers than for workers with a university degree. For ICT workers we find elasticities ranging between 0.67 for the percentage of workers using a computer at work and 0.23 for the percentage of workers with internet access. The former elasticity, for instance, indicate that a firm with a ten percent higher share of workers using a computer at workplace will have a higher share of ICT worker by about 0.6 percentage points (from a mean percentage share of 8.8 up to about 9.3 percent). Conversely, the elasticities of the share of university graduates with respect to the ratio of computers per worker are relatively small, ranging between 0.38 for university graduates with a five-year degree and 0.20 for workers with a four-year university degree. These elasticities indicate that a firm with a ten percent higher ratio of computers per worker will have a higher share of workers with a university degree by about 0.3 
Table 6: Determinants of skill structure (ML Tobit)

\begin{tabular}{|c|c|c|c|c|c|c|}
\hline & \multicolumn{6}{|c|}{ Dependent variables: employment shares } \\
\hline & $\begin{array}{c}\mathrm{ICT} \\
\text { workers }\end{array}$ & $\begin{array}{l}\text { university } \\
\text { five- } \\
\text { year }\end{array}$ & $\begin{array}{l}\text { degree } \\
\text { four- } \\
\text { year }\end{array}$ & $\begin{array}{l}\text { masters, } \\
\text { tech- } \\
\text { nicians }\end{array}$ & $\begin{array}{l}\text { vocat- } \\
\text { ional } \\
\text { school }\end{array}$ & $\begin{array}{c}\text { un- } \\
\text { skilled }\end{array}$ \\
\hline computers p. worker & $\begin{array}{l}0.121 \\
(13.24)\end{array}$ & $\begin{array}{l}0.089 \\
(11.01)\end{array}$ & $\begin{array}{c}0.031 \\
(4.58)\end{array}$ & $\begin{array}{c}0.000 \\
(0.01)\end{array}$ & $\begin{array}{c}-0.070 \\
(-5.26)\end{array}$ & $\begin{array}{c}-0.112 \\
(-6.19)\end{array}$ \\
\hline$\%$ using a computer & $\frac{0.112}{(7.31)}$ & $\begin{array}{c}0.075 \\
(5.66)\end{array}$ & $\begin{array}{c}0.069 \\
(6.39)\end{array}$ & $\begin{array}{c}0.002 \\
(0.11)\end{array}$ & $\begin{array}{c}-0.045 \\
(-2.22)\end{array}$ & $\begin{array}{c}-0.121 \\
(-5.10)\end{array}$ \\
\hline$\%$ with internet access & $\begin{array}{c}0.104 \\
(7.55)\end{array}$ & $\begin{array}{l}0.128 \\
(10.68)\end{array}$ & $\begin{array}{c}0.450 \\
(4.45)\end{array}$ & $\begin{array}{c}0.011 \\
(0.88)\end{array}$ & $\begin{array}{c}-0.101 \\
(-5.32)\end{array}$ & $\begin{array}{c}-0.103 \\
(-4.90)\end{array}$ \\
\hline databases, widespread & $\begin{array}{c}0.029 \\
(2.12)\end{array}$ & $\begin{array}{c}0.000 \\
(0.04)\end{array}$ & $\begin{array}{c}0.019 \\
(2.05)\end{array}$ & $\begin{array}{c}-0.026 \\
(-2.32)\end{array}$ & $\begin{array}{c}0.025 \\
(1.49)\end{array}$ & $\begin{array}{c}-0.011 \\
(-0.59)\end{array}$ \\
\hline database, occasional & $\begin{array}{c}0.027 \\
(2.47)\end{array}$ & $\begin{array}{c}0.013 \\
(1.18)\end{array}$ & $\begin{array}{c}0.012 \\
(1.37)\end{array}$ & $\begin{array}{c}-0.027 \\
(-2.53)\end{array}$ & $\begin{array}{c}0.023 \\
(1.43)\end{array}$ & $\begin{array}{c}-0.005 \\
(-0.13)\end{array}$ \\
\hline ERP, widespread & $\begin{array}{c}0.032 \\
(2.47)\end{array}$ & $\begin{array}{c}0.023 \\
(2.07)\end{array}$ & $\begin{array}{c}0.020 \\
(2.30)\end{array}$ & $\begin{array}{c}0.029 \\
(2.65)\end{array}$ & $\begin{array}{c}-0.023 \\
(-1.39)\end{array}$ & $\begin{array}{r}0.007 \\
(0.04)\end{array}$ \\
\hline ERP, occasional & $\begin{array}{c}0.025 \\
(2.00)\end{array}$ & $\begin{array}{c}0.037 \\
(3.57)\end{array}$ & $\begin{array}{c}0.015 \\
(1.75)\end{array}$ & $\begin{array}{c}0.024 \\
(2.31)\end{array}$ & $\begin{array}{c}-0.014 \\
(-0.90)\end{array}$ & $\begin{array}{c}-0.003 \\
(-1.06)\end{array}$ \\
\hline CAD, widespread & $\begin{array}{c}-0.023 \\
(-2.06)\end{array}$ & $\begin{array}{c}0.011 \\
(1.15)\end{array}$ & $\begin{array}{c}0.015 \\
(1.96)\end{array}$ & $\begin{array}{c}0.017 \\
(1.71)\end{array}$ & $\begin{array}{c}0.011 \\
(0.72)\end{array}$ & $\begin{array}{c}-0.092 \\
(-3.32)\end{array}$ \\
\hline CAD, occasional & $\begin{array}{c}-0.009 \\
(-1.01)\end{array}$ & $\begin{array}{c}0.015 \\
(2.00)\end{array}$ & $\begin{array}{c}-0.006 \\
(-0.98)\end{array}$ & $\begin{array}{c}0.010 \\
(1.24)\end{array}$ & $\begin{array}{c}-0.004 \\
(-0.31)\end{array}$ & $\begin{array}{c}-0.017 \\
(-0.13)\end{array}$ \\
\hline Email, widespread & $\begin{array}{c}-0.009 \\
(-1.00)\end{array}$ & $\begin{array}{c}0.033 \\
(1.91)\end{array}$ & $\begin{array}{c}0.012 \\
(0.92)\end{array}$ & $\begin{array}{c}0.004 \\
(0.27)\end{array}$ & $\begin{array}{c}0.001 \\
(0.03)\end{array}$ & $\begin{array}{c}0.001 \\
(0.04)\end{array}$ \\
\hline Email, occasional & $\begin{array}{c}0.000 \\
(0.01)\end{array}$ & $\begin{array}{c}0.016 \\
(0.97)\end{array}$ & $\begin{array}{c}0.010 \\
(0.78)\end{array}$ & $\begin{array}{c}0.009 \\
(0.59)\end{array}$ & $\begin{array}{c}-0.014 \\
(-0.61)\end{array}$ & $\begin{array}{c}0.001 \\
(1.07)\end{array}$ \\
\hline East Germany & $\begin{array}{c}-0.006 \\
(-0.66)\end{array}$ & $\begin{array}{c}0.071 \\
(9.05)\end{array}$ & $\begin{array}{c}0.012 \\
(1.91)\end{array}$ & $\begin{array}{c}-0.008 \\
(-0.96)\end{array}$ & $\begin{array}{c}0.048 \\
(3.94)\end{array}$ & $\begin{array}{c}-0.222 \\
(-11.71)\end{array}$ \\
\hline part of a group & $\begin{array}{c}-0.007 \\
(-0.83)\end{array}$ & $\begin{array}{c}0.018 \\
(2.54)\end{array}$ & $\begin{array}{c}0.010 \\
(1.71)\end{array}$ & $\begin{array}{c}-0.010 \\
(-1.34)\end{array}$ & $\begin{array}{c}0.005 \\
(0.45)\end{array}$ & $\begin{array}{c}-0.016 \\
(-1.03)\end{array}$ \\
\hline foreign subsidiary & $\begin{array}{c}-0.022 \\
(-2.41)\end{array}$ & $\begin{array}{c}0.017 \\
(2.15)\end{array}$ & $\begin{array}{c}0.012 \\
(1.84)\end{array}$ & $\begin{array}{c}0.002 \\
(0.21)\end{array}$ & $\begin{array}{c}-0.016 \\
(-1.25)\end{array}$ & $\begin{array}{c}-0.001 \\
(-0.35)\end{array}$ \\
\hline size, sector dummies & yes & yes & yes & yes & yes & yes \\
\hline constant & $\begin{array}{c}-0.242 \\
(-7.94)\end{array}$ & $\begin{array}{l}-0.258 \\
(-10.76)\end{array}$ & $\begin{array}{c}-0.075 \\
(-4.22)\end{array}$ & $\begin{array}{c}0.083 \\
(3.95)\end{array}$ & $\begin{array}{l}0.518 \\
(16.58)\end{array}$ & $\begin{array}{c}0.273 \\
(7.87)\end{array}$ \\
\hline scale factor & .572 & .723 & .745 & .713 & .957 & .630 \\
\hline percentage of censoring & .31 & .21 & .19 & .18 & .07 & .34 \\
\hline$\epsilon^{a}:$ computer p. worker & $0.47^{* *}$ & $0.31^{* *}$ & $0.13^{* *}$ & 0.00 & $-0.09^{* *}$ & $-0.25^{* *}$ \\
\hline$\epsilon^{a}:$ workers using comp. & $0.34^{* *}$ & $0.20^{* *}$ & $0.23^{* *}$ & 0.00 & $-0.05^{* *}$ & $-0.21^{* *}$ \\
\hline$\epsilon^{a}:$ internet access & $0.23^{* *}$ & $0.25^{* *}$ & $0.11^{* *}$ & 0.02 & $-0.07^{* *}$ & $-0.14^{* *}$ \\
\hline
\end{tabular}

Notes: see Table 5. ** $\left({ }^{*}\right)$ denote significant at the 5 (10) percent level.

Observations: 2947. 
and 0.1 percentage points, respectively. The elasticities of the share of workers with a five-year university degree with respect to the percentage of workers with internet access and the percentage of workers using a computer at the workplace are slightly smaller ranging between 0.04 and 0.19 . Among the different ICT indicators the relationship is strongest, in absolute values, for the ratio of computers per worker followed by both the percentage of workers using a computer on the job as well as the percentage of workers with internet access. The magnitude of relationship between ICT penetration and the percentage of unskilled workers is also relatively small in absolute values, with elasticities of the unskilled worker share with respect to ICT between -0.10 for the percentage of workers with internet access and -0.50 for the ratio of computers per worker. Thus a ten percent increase in one of the ICT indicators decrease the unskilled employment share between 0.1 and 0.3 percentage points. The elasticities of unskilled labor with respect to each of the three ICT penetration indicators are quite similar to the corresponding elasticities for high-skilled labor. This finding is therefore not in line with our second hypothesis suggesting limited substitutability between unskilled labor and the usage of ICT (Bresnahan 1999). Furthermore, as predicted, the elasticity of the unskilled labor share with respect to both the percentage of workers using a computer and the percentage of workers with internet access exceeds the elasticity of medium-skilled labor in absolute values indicating that ICT is a stronger substitute to unskilled labor than to medium-skilled labor. The elasticities of the share of workers with a certificate from the dual vocational system range between -0.10 for the ratio of computers per worker and -0.07 for the percentage of workers using a computer on the job.

Furthermore, the use of software applications such as ERP software, database management/datawarehouse software as well as CAD/CAE are also important determinants explaining the firms' skill structure. The strongest relationship between the different types of software applications can be observed between the use of database management systems and the share of ICT workers. A widespread or occasional use of database management systems is associated with a 11 and 7 percentage points higher share of ICT workers. This finding is consistent with our conjecture that database management systems require a larger 
number of ICT workers to maintain, support and to develop them. Furthermore, the widespread use of CAD/CAE software and tools is significantly positively related to workers with a university degree from a university of applied sciences as well as to masters and technicians. This is consistent with the conjecture that $\mathrm{CAD}$ applications require higher technical skills. Conversely, the use of $\mathrm{CAD} / \mathrm{CAE}$ software and tools is significantly negative related to the share of unskilled workers. Furthermore, the use of software for planning and controlling such as ERP software is significantly positive for masters and technicians. The use of e-mail does not appear to be an important determinant of the skill structure. Similarly, the coefficients on the dummy variables measuring the share of connected computers are not significant in most of the cases.

In order to examine whether the coefficients vary across different industries, we separately estimate the share equations for three different subsamples: (i) manufacturing firms excluding the ICT sector, (ii) ICT sector, (iii) services, including retail, wholesale trade, transport as well as business services excluding ICT-related services.

Table 7 presents the elasticities of the employment share with respect to the different ICT penetration indicators. For all subsamples we again find that highly skilled workers are complementary with the usage of ICT such as the percentage of workers with internet access, computers per worker and the percentage of workers using a computer at the workplace. For medium-skilled and unskilled labor the negative effect of ICT remains significant in most of the cases. In the ICT sector as well as in the service sector, the results show that a greater penetration of ICT tends to reduce the share of workers with a certificate from the dual vocational system. The negative impact of the penetration of ICT on workers with a vocational degree is consistent with Jacobebbinghaus and Zwick (2001) who found a significantly negative relationship between the share of workers with a certificate from the dual vocational system and the ICT investment sales ratio using firm level data for the German service sector. The relationship between ICT and the unskilled labor share remains significantly negative across all three subsamples, except for the coefficients on the percentage of workers with internet access in manufacturing and the share of workers using a computer. 
Table 7: Elasticities across different subsectors (based on CLAD)

\begin{tabular}{|c|c|c|c|c|c|c|}
\hline & $\begin{array}{c}\text { ICT } \\
\text { workers }\end{array}$ & $\begin{array}{l}\text { universit } \\
\text { five- } \\
\text { year }\end{array}$ & $\begin{array}{l}\text { degree } \\
\text { four- } \\
\text { year }\end{array}$ & $\begin{array}{l}\text { masters } \\
\text { techn. }\end{array}$ & $\begin{array}{l}\text { voc- } \\
\text { ational } \\
\text { degree }\end{array}$ & $\begin{array}{c}\text { un- } \\
\text { skilled }\end{array}$ \\
\hline & \multicolumn{6}{|c|}{ manufacturing excl. ICT sector $($ obs $=1392)$} \\
\hline computers per worker & $\begin{array}{c}0.362 \\
(4.20)\end{array}$ & $\begin{array}{l}0.537 \\
(8.07)\end{array}$ & $\begin{array}{c}0.214 \\
(4.39)\end{array}$ & $\begin{array}{l}0.042 \\
(1.38)\end{array}$ & $\begin{array}{c}-0.027 \\
(-0.92)\end{array}$ & $\begin{array}{c}-0.222 \\
(-3.49)\end{array}$ \\
\hline$\%$ using a computer & $\begin{array}{c}0.034 \\
(0.63)\end{array}$ & $\begin{array}{l}-0.049 \\
(-1.11)\end{array}$ & $\begin{array}{l}0.051 \\
(1.39)\end{array}$ & $\begin{array}{c}-0.009 \\
(1.43)\end{array}$ & $\begin{array}{l}0.011 \\
(0.71)\end{array}$ & $\begin{array}{l}-0.056 \\
(-1.06)\end{array}$ \\
\hline \multirow[t]{2}{*}{$\%$ internet access } & ${ }_{(1.64)}^{0.045}$ & $\begin{array}{c}0.083 \\
(2.53)\end{array}$ & $\begin{array}{c}0.086 \\
(4.05)\end{array}$ & $\begin{array}{c}0.006 \\
(0.35)\end{array}$ & $\begin{array}{c}-0.075 \\
(-3.64)\end{array}$ & $\begin{array}{c}-0.017 \\
(-0.77)\end{array}$ \\
\hline & \multicolumn{6}{|c|}{ ICT sector $(\mathrm{obs}=478)$} \\
\hline computers per worker & $\begin{array}{c}0.178 \\
(1.90)\end{array}$ & $\begin{array}{l}0.262 \\
(5.68)\end{array}$ & $\begin{array}{c}0.048 \\
(1.06)\end{array}$ & $\begin{array}{c}-0.037 \\
(-0.59)\end{array}$ & $\begin{array}{c}-0.043 \\
(-1.33)\end{array}$ & $\begin{array}{l}-1.166 \\
(-2.79)\end{array}$ \\
\hline$\%$ using a computer & $\begin{array}{c}1.078 \\
(4.80)\end{array}$ & $\begin{array}{c}0.682 \\
(3.28)\end{array}$ & $\begin{array}{c}0.370 \\
(2.88)\end{array}$ & $\begin{array}{c}-0.303 \\
(-2.35)\end{array}$ & $\begin{array}{c}-0.128 \\
(-2.05)\end{array}$ & $\begin{array}{c}-0.649 \\
(-1.61)\end{array}$ \\
\hline \multirow[t]{2}{*}{$\%$ internet access } & $\begin{array}{c}0.610 \\
(4.61)\end{array}$ & $\begin{array}{c}0.333 \\
(2.19)\end{array}$ & $\begin{array}{c}0.243 \\
(1.78)\end{array}$ & $\begin{array}{l}0.119 \\
(1.55)\end{array}$ & $\begin{array}{c}-0.153 \\
(-2.83)\end{array}$ & $\begin{array}{c}-0.359 \\
(-1.71)\end{array}$ \\
\hline & \multicolumn{6}{|c|}{ services excl. ICT sector (obs=1077) } \\
\hline computers per worker & $\underset{(4.17)}{0.486}$ & $\begin{array}{c}0.362 \\
(3.39)\end{array}$ & $\begin{array}{c}0.138 \\
(1.59)\end{array}$ & $\begin{array}{l}0.048 \\
(1.18)\end{array}$ & $\begin{array}{c}-0.140 \\
(-2.54)\end{array}$ & $\begin{array}{c}-0.466 \\
(-2.56)\end{array}$ \\
\hline$\%$ using a computer & $\begin{array}{c}0.072 \\
(1.48)\end{array}$ & $\begin{array}{c}0.166 \\
(1.89)\end{array}$ & $\begin{array}{l}0.191 \\
(2.46)\end{array}$ & $\begin{array}{c}0.021 \\
(1.04)\end{array}$ & $\begin{array}{c}-0.078 \\
(-1.56)\end{array}$ & $\begin{array}{l}-0.046 \\
(-0.53)\end{array}$ \\
\hline$\%$ internet access & $\begin{array}{l}0.017 \\
(1.88)\end{array}$ & $\begin{array}{l}0.353 \\
(5.30)\end{array}$ & $\begin{array}{l}0.053 \\
(1.07)\end{array}$ & $\begin{array}{l}-0.057 \\
(-0.62)\end{array}$ & $\begin{array}{l}-0.114 \\
(-3.68)\end{array}$ & $\begin{array}{l}-0.120 \\
(-1.57)\end{array}$ \\
\hline
\end{tabular}

Notes: Elasticities measure the percentage change of the employment shares on a one percent increase of each of the different ICT indicators. $t$-values in parentheses are based on bootstrap standard errors with 500 draws. 
Most importantly, consistent with our fourth hypothesis we find that the magnitude of the effects is considerably higher in the ICT sector than in the service or the manufacturing sector. For ICT workers as well as for high-skilled workers in case of workers using a computers on the job the elasticity range between 0.68 and 1.08. These elasticities are quite large, suggesting that a firm with a ten percent higher share of workers using a computer at workplace will have a higher share of workers with a five-year university degree or ICT workers by about 1.6 and 3.7 percentage points, respectively. Furthermore, we find that the negative relationship, in absolute values, between ICT and both the share of workers with a degree from the dual vocational system and the share of unskilled labor is larger in services than in manufacturing. This is consistent with our conjecture that routinization of many simple and repetitive white collar tasks tends to reduce the relative demand for medium-skilled workers in services. Similarly, for high-skilled labor higher than average elasticities can be found in the ICT sector, followed by service sector.

\subsection{Ordered probit estimates for expected employment movements}

To check the robustness of our results we also relate the expected change in each skill type's employment share to the initial ICT penetration variables. This may reduce the endogeneity problem of ICT in the employment share equation. Doms et al. (1997) argue that the correlation between technology use and the share of skilled workers using cross-section data is primarily due to the fact that firms with a skilled workforce are more likely to adopt technologies. As dependent variables we use five categorical variables indicating whether firms plan to increase, or decrease or expect stable employment of two types of highskilled workers, two types of medium-skilled workers between 2000 and 2002. Table 8 shows the results of ordered probit estimates. Note that the higher sample size compared to the employment share equations is due to the lower share of missing information on the employment expectations. Table 9 reports marginal effects of the right hand variables on the probability that a firm expects decreasing employment as well as on the probability of increasing employment. 
Table 8: Ordered probit estimates of expected employment change

\begin{tabular}{|c|c|c|c|c|c|}
\hline & \multicolumn{5}{|c|}{ Dep. variables expected employment change } \\
\hline & $\begin{array}{c}\text { five-year } \\
\text { university } \\
\text { degree }\end{array}$ & $\begin{array}{c}\text { four year } \\
\text { university } \\
\text { degree }\end{array}$ & $\begin{array}{c}\text { masters } \\
\text { techn. }\end{array}$ & $\begin{array}{l}\text { voc- } \\
\text { ational } \\
\text { degree }\end{array}$ & $\begin{array}{c}\text { un- } \\
\text { skilled }\end{array}$ \\
\hline computers per worker & $\begin{array}{l}0.26 \\
(3.89)\end{array}$ & $\begin{array}{l}0.14 \\
(2.31)\end{array}$ & $\begin{array}{l}-0.09 \\
(-1.82)\end{array}$ & $\begin{array}{l}-0.08 \\
(-1.73)\end{array}$ & $\begin{array}{l}-0.09 \\
(-2.20)\end{array}$ \\
\hline$\%$ using a computer & $\begin{array}{l}0.19 \\
(2.00)\end{array}$ & $\begin{array}{l}0.22 \\
(2.38)\end{array}$ & $\begin{array}{l}0.02 \\
(0.27)\end{array}$ & $\begin{array}{l}0.03 \\
(0.33)\end{array}$ & $\begin{array}{l}-0.04 \\
(-0.56)\end{array}$ \\
\hline$\%$ internet access & $\begin{array}{l}0.21 \\
(2.29)\end{array}$ & $\begin{array}{l}0.18 \\
(2.01)\end{array}$ & $\begin{array}{l}-0.10 \\
(-1.31)\end{array}$ & $\begin{array}{l}-0.04 \\
(-0.50)\end{array}$ & $\begin{array}{l}0.05 \\
(0.76)\end{array}$ \\
\hline databases, widespread & $\begin{array}{l}0.01 \\
(0.08)\end{array}$ & $\begin{array}{l}0.21 \\
(0.34)\end{array}$ & $\begin{array}{l}-0.02 \\
(-0.29)\end{array}$ & $\begin{array}{l}-0.10 \\
(-0.17)\end{array}$ & $\begin{array}{l}-0.05 \\
(-0.74)\end{array}$ \\
\hline database, occasional & $\begin{array}{l}0.07 \\
(1.19)\end{array}$ & $\begin{array}{l}0.66 \\
(1.16)\end{array}$ & $\begin{array}{l}-0.03 \\
(-0.56)\end{array}$ & $\begin{array}{l}0.07 \\
(1.13)\end{array}$ & $\begin{array}{l}-0.16 \\
(-2.70)\end{array}$ \\
\hline ERP, widespread & $\begin{array}{l}0.09 \\
(0.15)\end{array}$ & $\begin{array}{l}0.28 \\
(0.46)\end{array}$ & $\begin{array}{l}0.79 \\
(1.35)\end{array}$ & $\begin{array}{l}-0.03 \\
(-0.45)\end{array}$ & $\begin{array}{l}-0.14 \\
(-2.48)\end{array}$ \\
\hline ERP, occasional & $\begin{array}{l}-0.03 \\
(-0.05)\end{array}$ & $\begin{array}{l}0.07 \\
(1.16)\end{array}$ & $\begin{array}{l}0.10 \\
(1.87)\end{array}$ & $\begin{array}{l}-0.05 \\
(-0.88)\end{array}$ & $\begin{array}{l}-0.08 \\
(-1.50)\end{array}$ \\
\hline CAD, widespread & $\begin{array}{l}0.14 \\
(2.08)\end{array}$ & $\begin{array}{l}0.23 \\
(3.38)\end{array}$ & $\begin{array}{l}0.06 \\
(0.98)\end{array}$ & $\begin{array}{l}-0.02 \\
(-0.39)\end{array}$ & $\begin{array}{l}-0.15 \\
(-2.57)\end{array}$ \\
\hline CAD, occasional & $\begin{array}{l}0.10 \\
(2.00)\end{array}$ & $\begin{array}{l}0.11 \\
(2.05)\end{array}$ & $\begin{array}{l}0.10 \\
(2.17)\end{array}$ & $\begin{array}{l}0.03 \\
(0.71)\end{array}$ & $\begin{array}{l}-0.01 \\
(-0.30)\end{array}$ \\
\hline Email, widespread & $\begin{array}{l}-0.08 \\
(-0.11)\end{array}$ & $\begin{array}{l}0.57 \\
(0.69)\end{array}$ & $\begin{array}{l}0.08 \\
(0.97)\end{array}$ & $\begin{array}{l}0.10 \\
(1.23)\end{array}$ & $\begin{array}{l}0.03 \\
(0.41)\end{array}$ \\
\hline Email, occasional & $\begin{array}{l}-0.16 \\
(-2.41)\end{array}$ & $\begin{array}{l}-0.16 \\
(-2.14)\end{array}$ & $\begin{array}{l}0.03 \\
(0.34)\end{array}$ & $\begin{array}{l}0.01 \\
(0.14)\end{array}$ & $\begin{array}{l}0.09 \\
(1.22)\end{array}$ \\
\hline size, sector dummies & yes & yes & yes & yes & yes \\
\hline threshold 1 & -0.36 & -0.35 & -0.69 & -0.43 & -0.91 \\
\hline threshold 2 & 2.18 & 2.09 & 1.43 & 1.05 & 1.03 \\
\hline Pseudo $\mathrm{R}^{2}$ & 0.13 & 0.16 & 0.05 & 0.06 & 0.13 \\
\hline observations & 3756 & 3756 & 3756 & 3756 & 3756 \\
\hline
\end{tabular}


For both categories of workers with a university degree, the estimated coefficients for computers per worker, the percentage of workers using a computer on the job as well as the percentage of workers with internet access are positive and significant at the 5 percent level (see Table 8). Furthermore, the use of software applications such as CAD/CAE is also an important determinant of the employment expectations of high-skilled workers as well as masters and technicians.

The marginal effects indicate that the magnitude of ICT penetration on the probability of decreasing or increasing employment is relatively low. For instance, an increase of the percentage of workers using a computer at work of about 1 percent will rise the probability to increase employment of workers with a fiveyear university degree of about 0.012 percent on the one hand and lower the probability to decrease employment by -0.08 percent on the other hand (see Table 9).

This confirms the results for the high-skilled employment share equations from the previous section. Furthermore, the ratio of computers per worker is significantly negatively related to employment expectations for both medium- and unskilled labor confirming results for the employment share equation from the previous section. However, the relationship between employment expectations for workers with a vocational degree and either the percentage of worker using a computer on the job or the percentage of workers with internet access remains negative but is not significant at the five percent level.

\section{Conclusion}

This paper analyzes the link between both the skill structure and employment expectations and the use of information- and communication technology using firm level data. We distinguish between six different worker categories: workers with a five- and four-year university degree, masters and technicians, workers with a certificate from the dual vocational system, unskilled workers as well as skilled ICT workers. In order to account for the censoring of the employment shares we employ both semiparametric regression methods as well as standard ML Tobit 
Table 9: Marginal effects of the ordered probit model

\begin{tabular}{|c|c|c|c|c|}
\hline & \multicolumn{4}{|c|}{ Marginal Effects } \\
\hline & \multicolumn{2}{|c|}{ for $y=0$ "decrease" } & \multicolumn{2}{|c|}{ for $\mathrm{y}=2$ "increase" } \\
\hline & $\delta y / \delta x$ & $\mathrm{t}$ & $\delta y / \delta x$ & $\mathrm{t}$ \\
\hline & \multicolumn{4}{|c|}{ five-year university degree } \\
\hline computers per worker & -0.08 & -3.89 & 0.016 & 3.89 \\
\hline \% using a computer & -0.06 & -2.00 & 0.012 & 2.00 \\
\hline \multirow[t]{2}{*}{$\%$ internet access } & -0.07 & -2.29 & 0.013 & 2.29 \\
\hline & \multicolumn{4}{|c|}{ four-year university degree } \\
\hline computers per worker & -0.05 & -2.31 & 0.009 & 2.31 \\
\hline$\%$ using a computer & -0.08 & -2.38 & 0.013 & 2.38 \\
\hline \multirow[t]{2}{*}{$\%$ internet access } & -0.06 & -2.01 & 0.011 & 2.01 \\
\hline & \multicolumn{4}{|c|}{ masters / technicians } \\
\hline computers per worker & 0.03 & 1.82 & -0.011 & -1.82 \\
\hline$\%$ using a computer & -0.01 & -0.27 & 0.002 & 0.27 \\
\hline \multirow[t]{2}{*}{$\%$ internet access } & 0.03 & 1.31 & -0.013 & -1.31 \\
\hline & \multicolumn{4}{|c|}{ vocational degree } \\
\hline computers per worker & 0.03 & 1.73 & -0.017 & -1.73 \\
\hline$\%$ using a computer & -0.01 & -0.33 & 0.006 & 0.33 \\
\hline \multirow[t]{2}{*}{$\%$ internet access } & 0.01 & 0.50 & -0.008 & -0.50 \\
\hline & \multicolumn{4}{|c|}{ unskilled workers } \\
\hline computers per worker & 0.026 & 2.20 & -0.019 & -2.20 \\
\hline$\%$ using a computer & 0.013 & 0.56 & -0.010 & -0.56 \\
\hline \% internet access & -0.015 & -0.76 & 0.011 & 0.76 \\
\hline
\end{tabular}

Notes: Number of observations is 3756. Marginal effects are calcuated at the means. 
models. In addition, we use single equation ordered probit models to investigate the determinants of employment expectations. We find some significant differences between ML Tobit estimates to those estimated by semiparametric methods.

The main result is that the firms with a greater penetration of ICT employ a larger fraction of workers with a university degree, in particular workers with a five-year degree followed by workers with a four-year degree. The magnitude of this relationship is larger for computers per worker than for the percentage of workers using a computer on the job. In contrast, a greater penetration of ICT tends to reduce the share of both medium-skilled and unskilled workers. The results are consistent with the technology-skill complementarity hypothesis. Overall, the magnitude of these elasticities is quite small. A ten percent increase in the percentage of workers using a computer on the job or the ratio of computers per worker, for instance, tends to increase the share of university graduates between 0.1 and 0.3 percentage points depending on the ICT indicator. The larger effect of ICT on the share of ICT workers can be explained by the fact that these occupations are directly related to the usage of ICT in order to install, maintain or support them. As predicted, the elasticity of the unskilled labor share with respect to both the percentage of workers with internet access exceeds the elasticity of the medium-skilled labor in absolute values indicating that ICT is a stronger substitute to unskilled labor than to medium-skilled labor. We do not find, however, that the elasticity of high-skilled labor exceeds, in absolute values, the elasticity of unskilled labor with respect to each of the three ICT penetration indicators. This finding is therefore not in line with the prediction of limited substitutability between unskilled labor and ICT. Furthermore, the significantly positive relationship between ICT penetration and either high-skilled labor or ICT workers is considerably larger in the ICT sector than in the service or manufacturing sector. Similarly, the significantly negative relationship between both unskilled or medium-skilled labor and ICT penetration is more pronounced in the ICT sector than in services or manufacturing. Finally, the use of software applications such as ERPs, database management systems, as well as CAD/CAE is also a important determinant of the firms' skill structure. 


\section{References}

[1] Autor, D. H., L. F. Katz and A. B. Krueger, 1998, 'Computing Inequality: Have Computers changed the Labor Market', Quarterly Journal of Economics, 113, 4, 1169-1213.

[2] Bartel, A. and F. R. Lichtenberg, 1987, 'The Comparative Advantage of Educated Workers in implementing New Technology', Review of Economics and Statistics, 69, 1, 1-11.

[3] Berman, E., J. Bound and Z. Griliches, 1994, 'Changes in the Demand for Skilled Labor within U.S. Manufacturing: Evidence from the Annual Survey of Manufactures', Quarterly Journal of Economics 109, 2, 367-397.

[4] Breslaw, J. and J. McIntosh, 1998, 'Simulated Latent Variable Estimation of Models with Ordered Categorical Data', Journal of Econometrics, 87, 25-47.

[5] Bresnahan, T., 1999, 'Computerization and Wage Dispersion: An Analytical Reinterpretation', Economic Journal 109, 456, 390-415.

[6] Bresnahan, T., E. Brynjolfsson and L. Hitt, 2000, 'Information Technology, Workplace Organization and the Demand for Skilled Labor: Firm-level Evidence', mimeo, forthcoming: Quarterly Journal of Economics.

[7] Buchinsky, M., 1991, Methodological Issues in Quantile Regression, Chapter 1 of the theory and practice of Quantile regression. P.H. dissertation, Harvard University.

[8] Chennells, L. and J. Van Reenen, 1999, 'Has Technology hurt less Skilled Workers? An Econometric Survey of the Effects of Technical Change on the Structure of Pay and Jobs', IFS Working Paper 99-27, Institute for Fiscal Studies, London, UK.

[9] Doms, M., T. Dunne and K. R. Troske, 1997, 'Workers, Wages, and Technology', Quarterly Journal of Economics 112, 1, 253-290.

[10] Falk, M. and K. Seim, 2001a, 'Workers Skill Level and Information Technology: A censored regression model', International Journal of Manpower, 22,1, 98-120.

[11] Falk, M. and K. Seim, 2001b, 'The Impact of Information Technology on HighSkilled Labor in Services: Evidence from Firm Level Panel Data', ZEW Discus- 
sion Paper 99-58, forthcoming: Economics of Innovation and New Technology, 2001, 10.

[12] Jacobebbinghaus, P. and T. Zwick, 2001, 'New Technologies and the Demand for Medium-qualified labor in Germany', ZEW discussion paper 01-12, Mannheim.

[13] Jolliffe D., B. Krushelnytskyy and A. Semykina, 2000, 'Censored Least Absolute Deviations Estimator: CLAD', Stata Technical Bulletin, 58, 13-17.

[14] Kaiser, U., 2000, 'New Technologies and the Demand for Heterogeneous Labor: Firm-level Evidence for the German Business-Related Service Sector', Economics of Innovation and New Technology, 9, 5, 465-486.

[15] Kukuk, M., 2000, 'Informations- und Kommunikationstechnologien und die Arbeitsnachfrage nach unterschiedlichen Qualifikationen', paper presented at the German Economic Association congress in Berlin, 9/20/2000.

[16] Melenberg B. and A. Van Soest, 1996, 'Parametric and Semiparametric Modelling of Vacation Expenditures', Journal of Applied Econometrics, 11. 59-76.

[17] McDonald, J. and Y. J. Xu, 1996, 'A Comparison of Semi-Parametric and Partially Adaptive Estimators of the Censored Regression Model with Possibly Skewed and Leptokurtic Error Distributions', Economics Letters 51, 2, 153-59.

[18] Paarsch, H., 1984, 'A Monte Carlo Comparison of Estimators for the Censored Regression Model', Journal of Econometrics 24, 197-213.

[19] Powell, J., 1984, 'Least Absolute Deviations Estimation for the Censored Regression Model', Journal of Econometrics 25, 303-325.

[20] Powell, J., 1986, 'Symmetrically Trimmed Least Squares Estimation for Tobit Models', Econometrica, 54, 6, 1435-1460.

[21] Siegel, D., 1998, 'The Impact of Technological Change on Employment: Evidence From a Firm-Level Survey of Long Island Manufacturers', Economics of Innovation and New Technology, 5, 2, 227-246.

[22] Statistisches Bundesamt, 2001, 'Leben und Arbeiten in Deutschland, Ergebnisse des Mikrozensus 2000'. 